\title{
THE CHARACTER AND THE CONCLUSION: BERTRAM AND THE ENDING OF "ALL'S WELL THAT ENDS WELL"
}

\author{
William Babula \\ University of Miami
}

The ending of All's Well that Ends Well has been a problem for critics. Yet some of the difficulties have been spawned by a critical unwillingness to watch the character Bertram closely as he moves through the play. For the most part the reconciliation and Bertram's "conversion" at the conclusion of All's Well have been explained in the same way that the conclusion of Measure for Measure has been explained. ${ }^{1}$ But, as obvious as it may sound, Bertram is not Angelo, and our responses to the conclusions of the plays are not interchangeable. In Shakespeare's Sexual Comedy (New York: Bobbs-Merrill, 1971), pp. 152-3, Hugh M. Richmond, writing of Bertram, states: "For once, the naked truth about adolescent passions is objectively presented without any of the offsetting virtues which make the behavior of a Romeo tolerable." Richmond may go too far but he is close to the central point: the audience is dealing with the passion of a foolish adolescent. In a recent essay, W. W. Bernhardt argues that Troilus and Cressida achieves a certain unity through the character of Troilus whom Shakespeare presents as a "very confused young man." 2 To respond properly to the reconciliation at the end of All's Well we must recognize Bertram's character: he has been a foolish boy throughout the entire play-something that cannot be said about Angelo.

In the opening scene Bertram has just lost a father, and is to be a "ward" of the king. Lafeu comments, consoling mother and son: "You shall find of the king a husband, madam; you, sir, a father ..." (I, i, 8-9). ${ }^{3}$ Shakespeare reconstructs a family to remind the audience how much the boy Bertram needs one. In contrast, when the Countess calls Helena daughter, she, for obvious reasons, says: "I am not" (I, iii, 159). The restricted Bertram goes to Paris at "his majesty's command" while Helena freely chooses to go. As Bertram departs, his mother terms him "an unseason'd courtier," which he is. Once at court he is treated like a child; he complains that the King will not let him go to the wars: "I am commanded here, and kept a coil with 'Too Young,' and 'Tis too early' " (II, i, 27-28). In contrast, Angelo has no parents on stage and he is mature enough to be trusted with the rule of Vienna. In All's Well Shakespeare forces us to acknowledge the immaturity-physical as well as mental-of Bertram.

Then suddenly this boy finds himself married to Helena. If she is a "poor unlearned virgin," he is a very nervous one. Sexually inexperienced, like Leander in Marlowe's poem, he may just not 
know what to do. He is certainly befuddled, as his own apology to Helena suggests:

You must not marvel, Helena, at my course,

Which holds not colour with the time, nor does

The ministration and required office

On my particular. Prepared I was not

For such a business. Therefore am I found

So much unsettled. ... (II, v, 63-68)

He is "unsettled," not "prepared"; Bertram is showing his sexual insecurity. Even suggestions of impotency appear in Lafeu's comments on anyone who would refuse the apparently desirable Helena. The implication of his remark that anyone who rejects her should be made a "eunuch" is that he might as well be one. Implying sexual coldness, of all "this youthful parcel," including Bertram, Lafeu says: "These boys are boys of ice. .." (II, iii, 99). Yet any serious suggestion of impotency is undercut by Lafeu's repeated reference to the bachelors as "boys." Bertram is not ready to assume his role. When he flees his wife, his mother refers to him as one of twenty "rude boys" who should serve a lord worthy of Helena. For disobeying the king, she calls him a "rash and unbridled boy." And according to Helena he has "tender limbs." Perhaps Bertram appears most childish when he doesn't know that she is asking for a farewell kiss (II, v). ${ }^{4}$ He sounds most like a child when he terms himself a "hater of love." Though he refers to a "detested wife," his rejection seems general; it is of all love and, for the moment, of all sex. Bertram is the real "poor unlearned virgin" of the opening of the play.

With this idea of Bertram's character in mind, we might very well see how he has been unsettled by Helena. The audience has seen Helena in the first scene jesting with the bawdy Parolles, talking about losing her virginity "to her own liking." She has the sexual confidence Bertram lacks. She, in fact, takes on the usual masculine role of a kind of knight. She declares, like a knight out of a romance: "Who ever strove / To show her merit, that did miss her love?" (I, i, 241-242). Her deeds will make her worthy of the prize (Bertram). At court she risks death to get the desired reward. She promises the king:

If I break time, or flinch in property

Of what I spoke, unpitied let me die,

And well deserved: not helping, death's my fee. . . .

$$
\text { (II, i, 190-192) }
$$

The threat to her is real: if the sickly king dies she dies too. Of course she effects the cure and earns the right to choose a husband from among the young lords. Her promise has been fulfilled in a double sense. 
In contrast, however, the lords only have potential. The most the king can say about them is that each "had a noble father." Unlike Helena, they have achieved nothing. Bertram in particular is always presented in terms of his potential to be like his noble father. His mother tells him: "Succeed thy father / In manners, as in shape! ..." (I, i, 70-71). The king, noting that Bertram has his "father's face," hopes: "Thy father's moral parts / Mayst thou inherit too!" (I, ii, 21-22). Even when he goes to war he is made a general only by the "hope" of his "promising fortune." Bertram has only potential while Helena has achieved her current goal. The match is simply not proper; it yokes together a boy and a woman. Helena said of Bertram: "Nor would I have him till I do deserve him" (I, iii, 205); unconsciously Bertram may be feeling the same thing about himself. After the wedding, Parolles makes excuse for him to Helena:

A very serious business calls on him.

The great prerogative and rite of love,

Which, as your due, time claims, he does acknowledge

But puts it off to a compell'd restraint,

Whose want, and whose delay, is strew'd with sweets,

Which they distil now in the curbed time. ... (II, iv, 41-46)

Ironically, Parolles is right. His sexual immaturity is part of the "compell'd restraint." But it is also true that a "serious business calls on him." He must assume the masculine role; he must feel himself the wooer. Ultimately, he must fulfill the promise in his potential as his wife has fulfilled her promise to the king.

While Bertram's letter imposes new tasks upon Helena, and these tasks are necessary for the continuation of the drama, the real task is Bertram's. His wife had faced death and won him as a prize; it is only fitting that he too face death before he can deserve Helena. On the other hand, he must physically mature, no longer playing the boy to Helena's woman. The wars are obviously the best place to face the death his wife faced and to fulfill part of his promise (potential). And indeed he does. He takes "their greatest commander" and kills "the duke's brother." His "honourable service" is necessary to make him the equal of the kinetic Helena.

Having proven himself in war, his confidence grows. Though there is some question of when he began trying to seduce Diana, the audience doesn't hear of it until after it hears of his exploits in war. Thus it seems that he is now ready for a second proof of himself. Yet this new sexual energy first produces lust. While he does not seem a "eunuch" or a boy of ice now, his sexuality is misdirected-the fault, as several characters in the play suggest, of Parolles.

Yet while he is sexually confident, no longer a nervous and 
unsettled boy, he cannot seduce Diana. He is foolish enough to employ Parolles as his pander, but this character, in the space of one hundred lines in IV, iii, speaks of him as "a foolish idle boy," a "young boy," and advises Diana for his own sexual profit: "Men are to mell with, boys are not to kiss." Obviously Parolles still sees him as an adolescent. But a different note is sounded by Helena after her hour in bed with him: "O strange men! / That can such sweet use make of what they hate. ." (IV, iv, 21-22). Bertram no longer fits Parolles' description of him.

Though physically mature, however, he is not so mentally. From one extreme, that of a nervous adolescent, he has gone to another; he would be what Parolles calls him in the mock interrogation, " a whale to virginity." He displays Diana and talks freely of his attempt to seduce her (III, vi). When he believes he has won her, he obviously brags about his conquest. The lords seem to know all the details and he seems quite pleased with himself. As one lord points out, Bertram "thinks himself made in the unchaste composition" (IV, iii, 21-22). He is also among those who are "trumpeters of our unlawful intents" (IV, iii, 32). He is now the bragging conqueror of virginity. This tendency in Bertram's character also appears in his relationship with Parolles. While all others see through him, Bertram trusts him implicitly. When Parolles is revealed for what he is in the drum plot, Bertram goes to the opposite extreme. The other lords are amused by him, while Bertram wants him "whipped through the army." Parolles has become totally obnoxious to him. He has moved from one foolish extreme to another. Yet Bertram should take heed of what Parolles says after his exposure:

Who knows himself a braggart,

Let him fear this, for it will come to pass

That every braggart shall be found an ass. (IV, iii, 370-372)

It is a warning for the now overconfident Bertram.

With the war over and Helena presumed dead, this now too confident Bertram returns to France. Everything seems to be going well for him. He has regained the king's favor and a good marriage is in prospect. As Joseph G. Price comments: "We can imagine Bertram's supreme confidence as he answers the king's question about Lafeu's daughter."5 Bertram responds:

Admiringly, my liege, at first

I stuck my choice upon her, ere my heart

Durst make too bold a herald of my tongue:

Where the impression of mine eye infixing,

Contempt his scornful perspective did lend me,

Which warp'd the line of every other favour;

Scorn'd a fair colour, or express'd it stolen; 
Extended or contracted all proportions

To a most hideous object: thence it came

That she whom all men praised and whom myself,

Since I have lost, have loved, was in mine eye

The dust that did offend it. ( $\mathrm{V}$, iii, 45-55)

His reply is courtly and contrived; he manages to use this woman as an excuse for his behavior. At this point, he is the opposite of the unsettled boy who fled France; he believes he can get away with anything. "Psychologically as well as morally, Bertram is ripe for a fall."6

Shakespeare now moves towards a somewhat matured Bertram by striking a balance between the two extremes of nervous adolescent and conquering warrior and lover. Bertram must be, as he is, humiliated in this last scene to reach some maturity. As the scene develops, Bertram again appears as a child trying lie after lie to keep the favor he had just won back. While he is certainly unattractive as he slanders Diana, yet at least the last line he speaks before Helena enters is the truth. Of Diana's charge he now admits: "My lord, I do confess the ring was hers" (V, iii, 231). It is not much, but there seems to be the potential for honesty here. When Helena enters and says, "'Tis but the shadow of a wife you see, / The name and not the thing" (V, iii, 308-309), he immediately accepts her. There are no questions asked about the tasks he had required of her. Apparently he has matured enough to recognize the value of his wife. And though he is culpable in many ways, he deserves Helena more at this point, having at least put some of his potential into action, than when Helena first chose him.

With the strutting hero dressed down, the conversion and reconciliation take place. Critics who are not cynical about the ending tend to see in it the spiritual rebirth of Bertram. G. Wilson Knight argues that Bertram is forgiven by a Helena who is as merciful as Christ. ${ }^{7}$ R. G. Hunter suggests that the Elizabethan audience would refer the ending "to a belief in the reality of the descent of grace upon a sinning human."8 One critic specifically terms what happens to Bertram a "spiritual rebirth" and writes of his last speech: "He resolves to become a new man . . . at least momentarily, he can manage little more than baby talk."9 All of this sounds like the critics on Angelo in Measure for Measure.

Are such extremes of interpretation necessary? In rejecting such notions Price comments: "Shakespeare tells the story of a foolish young man who is brought to a true understanding of honour through the love of a virtuous girl."10 Again, the character of Bertram matters. He is young; he has been foolish and immature. These are difficulties, however, that can be overcome without divine assistance. What matters most is time. When Helena 
speaks of the happy ending, she refers it to the processes of time and nature, not the supernatural. The spring (the boyhood of Bertram) is, according to Helena, coming to an end:

But with the word the time will bring on summer,

When briers shall have leaves as well as thorns,

And be as sweet as sharp. We must away;

Our waggon is prepared, and time revives us. ...

(IV, iv, 31-34)

Time will mature the briers, and time has begun to mature the returned Bertram.

Thus there is no reason to see in the conclusion the "rebirth" of Bertram. In terms of the play, Bertram has grown up, barely. Again the potential Bertram must not be ignored. He has not become a "new man"- he is not Angelo-he has simply stopped being a boy. If we accept him as such it is hard to be either cynical or spiritual about the conclusion. We have none of the spiritual depravity that has been growing for nineteen years in the Vienna of Angelo. While Bertram has been foolish, Helena and the audience only have to wait for him to mature. When he does-an event that is rapid and seems more important for time future than for time present-by accepting his wife, he can naturally assume his role as husband. $\mathrm{He}$ is no longer nervous or overconfident. Thus the reconciliation is based finally not on the supernatural, but on time and maturation. Bertram had to prove himself, had to face death, as his wife did. He had, like Helena, to turn his potential into kinetic energy. The tasks Bertram must do are no less difficult than the tasks Helena must do. In fact, Bertram, running behind, must catch up. He must prove, though he does it unconsciously, that he deserves Helena. When he does so in the wars he takes the first step. Then he matures physically as he gains sexual confidence. Finally he truly matures, after the humiliation of the last scene, and is ready for proper sexual activity with Helena. ${ }^{11}$ Yet, we can agree with the king that only potentially all "seems well." 12 It is almost as if we have to trust that what has started will continuethat Bertram will continue to mature, that his potential will continue to be fulfilled. ${ }^{13}$ The character of Bertram, in its potential, makes sense of the reconciliation that concludes All's Well.

\section{NOTES}

1. One approach has stressed the conventional nature of the events in both plays: W. W. Lawrence, Shakespeare's Problem Comedies (New York: Macmillan, 1931), for example. More recently Robert Y. Turner has suggested that the conclusion of All's Well is shaped by dramatic conventions, but that these "have lost their savor" in "Dramatic Conventions in All's Well that Ends Well," PMLA, 75 (December, 1960), 497-502. Others have seen both plays as cynical. Una Ellis-Fermor writes of All's Well: "The conclusion is as cynical as that of 
Troilus; more so, perhaps, in its implications," in The Jacobean Drama, 4th ed. rev. (1958; rpt. London: Methuen, 1961), p. 260. In the same work (p. 260) she writes, "In Measure for Measure the lowest depths of Jacobean negation are touched. Cynicism has taken a kind of diabolic vigilance...." The only difference appears to be in intensity. A third approach sees in the conclusions "rebirths" of the fallen characters. This approach will be discussed later.

2. W. W. Bernhardt, "Shakespeare's Troilus and Cressida and Dryden's Truth Found Too Late," SQ, 20 (Spring, 1969), 129-141.

3. All references in my text are to Hardin Craig's, The Complete Works of Shakespeare (Glenview, Ill.: Scott, Foresman, 1961).

4. The scene, of course, could be played to make Bertram consciously cruel.

5. The Unfortunate Comedy: A Study of "All's Well that Ends Well" and Its Critics (Toronto: University of Toronto Press, 1968), p. 168.

6. Price, p. 169.

7. "The Third Eye" in The Sovereign Flower (New York: Macmillan, 1958), p. 146. This interpretation of the ending parallels Knight's explanation of the end of Measure for Measure with references to the spirit of charity embodied in the Sermon on the Mount in "Measure for Measure and the Gospels," in The Wheels of Fire (London: Oxford University Press, 1930), pp. 80-106. Once again the distinction between Bertram and Angelo is somewhat blurred.

8. Shakespeare and the Comedy of Forgiveness (New York: Columbia University Press, 1965), p. 30. Hunter continues to say, however, that we (the modern audience) "do not believe in the regeneration. It's not communicated to us" (p. 131). Like Knight, Hunter sees both Angelo and Bertram as sinners who require supernatural grace.

9. J. Dennis Huston, “'Some Stain of Soldier': The Function of Parolles in All's Well that Ends Well," SQ, 21 (Autumn, 1970), 434. To see Parolles as a "youth" as Huston does (p. 437) detracts from our sense of the extreme immaturity of Bertram. In the 1970 production of All's Well at the Asolo State Theater, Sarasota, Florida, Bertram was played by a very young actor and Parolles by a middle aged man. The contrast emphasized the childishness of Bertram.

10. The Unfortunate Comedy, p. 171.

11. For a different view of love and sex in the play see Carl Dennis, "All's Well that Ends Well and the Meaning of Agape," PQ, 50, 75-84.

12. David M. Bergeron in "The Structure of Healing in All's Well that Ends Well," South Atlantic Bulletin, 37 (November, 1972), 25-34, argues, however, that the cure is oomplete. In reference to both Parolles and Bertram he comments: "The old self is repealed and a new or truer self emerges" (p. 33).

13. Sylvan Barnet in the introduction to his edition of All's Well (New York: New American Library, 1965), pp. xxi-xxxix, suggests that only "a happy beginning is in store for Helena and Bertram" (p. xxxviii). But he has no doubts about what is beginning: "The story is over, the characters live happily ever after. ..." (p. xxxix). I don't think the play allows us to be so certain. 